\title{
Effect of Time of Application, Types and Concentrations of Plant Growth Regulators on Biochemical Parameters of Kinnow Mandarin
}

\author{
Aditi Bharti ${ }^{1 *}$, Kumari Karuna, Hidayatullah Mir, Shashi Kala and Ankita Aman \\ Department of Horticulture (Fruit \& Fruit Technology), Bihar Agricultural University, \\ Sabour (Bhagalpur), India \\ *Corresponding author
}

A B S T R A C T

\section{Ke y w o r d s \\ Kinnow mandarin, PGRs, Biochemical parameters \\ Article Info \\ Accepted: \\ 05 February 2020 \\ Available Online: \\ 10 March 2020}

The study was undertaken to envisage the effect of growth regulators on biochemical parameters of Kinnow mandarin. Various concentrations of 2,4-D, GA3 and NAA were applied on $15^{\text {th }}$ of October and $15^{\text {th }}$ of November separately and in both the months. It was observed that biochemical parameters viz. TSS, TA, TSS:TA, total sugar, ascorbic acid and other antioxidant compounds were maximum when trees were sprayed with 20 ppm NAA in both the months $\left(15^{\text {th }}\right.$ October $+15^{\text {th }}$ November $)$.

\section{Introduction}

Citrus is an important genus of the family Rutaceae in the plant kingdom. Citrus is native to tropical and subtropical region of Southeast Asia particularly, India and China. Citrus occupies about $14.9 \%$ of the total land under various fruit crops in India. Currently, citrus is cultivated in an area of 1003 ('000 HA) with total production of 12546 ('000 MT) and average productivity is 10.3 metric tonnes in India (NHB, 2018-19).

Kinnow is one of the important fruit crops among citrus species and occupies $54.9 \%$ area under citrus. It was developed by H.B. Frost at Citrus Experiment Station, California in 1915 by crossing King (Citrus nobilis) and Willow Leaf (Citrus deliciosa). It was introduced in the year 1949 in Punjab. It is highly prized and economically remunerative fruit. Kinnow is commercially cultivated due to its good yield, high processing quality, fresh consumption aromatic flavour and better adaptation to agro environmental condition of Punjab (Ahmed et al., 2006).

Being rich in vitamin- $\mathrm{C}$, a powerful antioxidant, it is considered to be an important part of human nutrition and helps in preventing many serious diseases and scavenges the reactive oxygen species 
produced in the body. Total soluble solids measurement is considered to be an important parameter of quality of kinnow fruits. Biochemical parameters of fruit depend upon the combined net effect of energy, water flow into and out of the fruit, functioning of enzymes responsible for physiological process. Biochemical parameters are also affected by the environmental factors, time of fruit harvesting, plant vigour and by application of growth regulators. These qualities could be increased by application of various plant growth regulators at certain period of time before harvesting of fruits.

2,4-Dichlorophenoxy acetic acid is a synthetic phenoxy compound stimulates the functioning of a number of enzymes in physiological process which caused an increase in chemical composition of fruit. The increase in Ascorbic acid content of fruit by 2,4-D treatment may be due to perpetual synthesis of glucose-6phoshphate throughout the growth and development of fruits which is thought to be precursor of vitamin C (Singh et al. 1986). Furthermore, auxin causes diversion of Nutrients and organic substances to the developing fruits (metabolic sink) from leaves and other parts of plant which ultimately accumulated with in fruits.

Gibberellins include a large number of chemicals that are produced naturally within plants that helps in mobilization of food material used for growth of cells and helps in improving fruit quality (Gurung et al 2016).

Therefore, effective supply of plant growth regulators is necessary to produce high quality fruits which involve selection of appropriate plant growth regulators and their combination, rate and time of application.

Moreover, Kinnow mandarin has been recently introduced in climatic conditions of Bihar, therefore the present experiments were conducted to study improvement in fruit quality by the application of 2,4-D, GA, NAA and their combinations.

Bihar Agricultural University; Sabour, Bhagalpur is situated at longitude $87^{\circ} 2^{\prime} 42^{\prime}$ ' East and latitude $25^{\circ} 15^{\prime} 40^{\prime \prime}$ North at an altitude of $46 \mathrm{~m}$ above mean sea level in the heart of vast Indo-Gangatic plains of North India. The climate of this place is sub-tropical characterized with hot desiccating summer, cold winter and moderate rainfall. May is the hottest month with an average maximum temperature of 35 to $39^{\circ} \mathrm{C}$. January is the coldest month of the year with mean minimum temperature varies from 5 to $10^{\circ} \mathrm{C}$.

The average annual rainfall is $1380 \mathrm{~mm}$, precipitating mostly between mid-June to mid-October. The Bihar Agricultural University, Sabour lays in Agro-climatic zone III A (NARP, Zone of the state) comprising 6 districts viz; Bhagalpur, Banka, Munger, Jamui, Lakhisarai and Sheikhpura of Bihar are having diverse type of topography and soil classes.

The meteorological data recorded during the experimentation period (2016-17) based on observations made at the meteorological observatory of the Bihar Agricultural University, Sabour are presented in Table 1.

\section{Materials and Methods}

The experiment was carried out in high density orchard of the Kinnow mandarin of Bihar Agricultural College, Sabour, Bhagalpur. Six years old, 57 plants of Kinnow mandarin of uniform size and age was selected for this experiment. The selected tress were tagged and given uniform cultural practices throughout the period of study. On the selected trees 2,4-D (10 and $20 \mathrm{ppm}$ ), GA3 (25 and50 ppm) and NAA (10 and 20 $\mathrm{ppm})$ were sprayed on $15^{\text {th }}$ October, $15^{\text {th }}$ 
November and in both the months to check the effect on pre-harvest fruit drop and physical properties of the fruits. The experiment consisted of 19 treatments including control, replicated thrice and single tree was taken as an experimental unit.

\section{Total soluble solids (TSS) ${ }^{\circ}$ brix}

The total soluble solids of samples was estimated using digital hand Refractometer and the results was expressed as degree brix ( ${ }^{\circ}$ Brix) at $20^{\circ} \mathrm{C}$ (Rangana, 2010). Titratable acidity was determined using titration method (Rangana, 2010). For this $2 \mathrm{~g}$ of fruit sample was weighed and added to $50 \mathrm{ml}$ water. It was thoroughly mixed and then filtered. The filtered sample was titrated against $0.1 \mathrm{~N}$ $\mathrm{NaOH}$ using a few drops of $1 \%$ phenolphthalein solution as indicator. The observed titre value was used for calculating acidity and the results were expressed as percentage of citric acid.

Total Acidity $(\%)=$

titre value $\mathrm{x} \mathrm{N}$ of alkali $\mathrm{x}$ eq.wt. of alkali x volume made up $\mathrm{x} 100$

wt. of sample $\mathrm{x}$ volume of sample for estimation $\mathrm{x} 1000$

TSS/Acid ratio- It was calculated by dividing the TSS with total acidity and results was expressed in per cent.

Vitamin-C in juice was estimated according to the method described by Ruck (1961) whereas sugars in juice were estimated by using Lane and Eyon method (1923) described by Hortwitz (1960).

Statistical analysis and interpretation of data The experimental data were subjected to statistical analysis in order to find out which of the treatments showed significant variation in different parameters/attributes studied under investigation. The technique of analysis of variance (ANOVA) for randomized block design (RBD) was adopted as suggested by
Panse and Sukhatme (1967).

\section{Results and Discussion}

Foliar application of NAA, particularly at 20 ppm, significantly improved T.S.S., Acidity, TSS- Acid ratio, and ascorbic acid content of fruit. Spraying of NAA $(20 \mathrm{ppm})$ on $15^{\text {th }}$ October $+15^{\text {th }}$ November recorded the maximum values of T.S.S., Acidity, TSSAcid ratio, and ascorbic acid content. Different workers in many fruit crops have reported similar results. However, our results were contradictory with that of Bhat et al., (2016). In their investigation they observed different quality parameters like T.S.S., ascorbic acid, acidity were reduced with the foliar application of NAA $200 \mathrm{ppm}+100$ ppm. Singh and Mishra (1986) indicated that phenoxy compounds (2,4-D or 2,4,5-T) increased the acidity level in Kinnow fruit.

The increased TSS, reducing sugar, total sugars and acidity content of fruit in our study might be explained that 2,4-D stimulates the functioning of a number of enzymes in physiological process which probably caused an increase in chemical composition of fruit.

The other explanation for this might be long period during which more accumulation of photosynthates especially carbohydrates occurred within them. The increase in Ascorbic acid content of fruit by 2,4-D treatment may be due to perpetual synthesis of glucose 6 phoshphate throughout the growth and development of fruits which is thought to be precursor of vitamin C (Singh et al. 1986). Furthermore, auxin caused diversion of Nutrients and organic substances to the developing fruits (metabolic sink) from leaves and other parts of plant which ultimately accumulated with in fruits. It was also found that total flavanoids content and phenolics content was not improved with the foliar spray of plant growth regulators. 
Table.1 Weather conditions prevailing during experimentation (July 2016 to February 2017)

\begin{tabular}{|c|c|c|c|c|c|}
\hline \multirow{2}{*}{$\begin{array}{c}\text { Standard meteorological } \\
\text { weeks } 2016-17\end{array}$} & \multicolumn{2}{|c|}{ Temperature $\left({ }^{\circ} \mathrm{C}\right)$} & \multicolumn{2}{|c|}{ Relative Humidity (\%) } & \multirow{2}{*}{$\begin{array}{c}\text { Rain fall } \\
(\mathbf{m m})\end{array}$} \\
\hline & Max. & Min. & 07.00 A.M. & 02.00 P.M. & \\
\hline 27 & 30.8 & 25.3 & 93.0 & 84.0 & 204.1 \\
\hline 28 & 32.5 & 25.7 & 90.0 & 78.0 & 43.4 \\
\hline 29 & 31.5 & 25.5 & 89.0 & 84.0 & 40.9 \\
\hline 30 & 31.8 & 25.8 & 89.0 & 76.0 & 14.9 \\
\hline 31 & 33.1 & 25.6 & 87.0 & 74.0 & 1.4 \\
\hline 32 & 32.8 & 25.9 & 88.0 & 76.0 & 26.9 \\
\hline 33 & 35.0 & 25.8 & 86.0 & 80.0 & 35.1 \\
\hline 34 & 31.0 & 25.5 & 84.0 & 74.0 & 4.8 \\
\hline 35 & 33.4 & 26.2 & 89.0 & 74.0 & 2.2 \\
\hline 36 & 31.1 & 24.6 & 91.0 & 84.0 & 147.3 \\
\hline 37 & 31.7 & 25.5 & 89.0 & 76.0 & 11.4 \\
\hline 38 & 31.7 & 24.4 & 91.0 & 80.0 & 42.4 \\
\hline 39 & 30.1 & 23.7 & 89.0 & 83.0 & 119.6 \\
\hline 40 & 32.6 & 25.2 & 86.0 & 74.0 & 23.2 \\
\hline 41 & 30.9 & 23.9 & 92.0 & 77.0 & 8.6 \\
\hline 42 & 32.2 & 20.3 & 87.0 & 60.0 & 00.0 \\
\hline 43 & 31.0 & 19.6 & 90.0 & 62.0 & 00.0 \\
\hline 44 & 30.6 & 18.6 & 90.0 & 65.0 & 00.0 \\
\hline 45 & 30.6 & 16.2 & 86.0 & 61.0 & 00.0 \\
\hline 46 & 29.3 & 13.6 & 92.0 & 51.0 & 00.0 \\
\hline 47 & 27.8 & 11.9 & 92.0 & 48.0 & 00.0 \\
\hline 48 & 27.1 & 12.6 & 92.0 & 62.0 & 00.0 \\
\hline 49 & 23.0 & 11.7 & 96.0 & 72.0 & 00.0 \\
\hline 50 & 18.7 & 8.0 & 97.0 & 75.0 & 00.0 \\
\hline 51 & 23.3 & 8.2 & 95.0 & 59.0 & 00.0 \\
\hline 52 & 23.0 & 10.0 & 96.0 & 74.0 & 00.0 \\
\hline 1 & 20.9 & 8.6 & 98.0 & 76.0 & 00.0 \\
\hline 2 & 21.3 & 8.0 & 96.0 & 61.0 & 00.0 \\
\hline 3 & 22.7 & 6.0 & 93.0 & 48.0 & 00.0 \\
\hline 4 & 25.1 & 8.2 & 91.0 & 59.0 & 12.4 \\
\hline 5 & 22.2 & 8.0 & 98.0 & 63.0 & 00.0 \\
\hline 6 & 25.8 & 7.9 & 89.0 & 51.0 & 00.0 \\
\hline 7 & 26.6 & 9.5 & 95.0 & 46.0 & 00.0 \\
\hline 8 & 28.4 & 11.5 & 86.0 & 44.0 & 00.0 \\
\hline 9 & 29.2 & 10.5 & 83.0 & 36.0 & 00.0 \\
\hline
\end{tabular}


Table.1 Effect of different treatment on T.S.S, Acidity, TSS/Acidity, Ascorbic Acid and Sugars

\begin{tabular}{|c|c|c|c|c|c|c|c|c|c|}
\hline Treatment & Chemical & $\begin{array}{c}\text { Concent } \\
\text { ration }\end{array}$ & $\begin{array}{c}\text { Date of } \\
\text { spray }\end{array}$ & $\begin{array}{l}\text { TSS } \\
\left(\begin{array}{c}0 \\
(\mathrm{~B})\end{array}\right.\end{array}$ & $\begin{array}{c}\text { Titratable } \\
\text { Acidity (\%) }\end{array}$ & $\begin{array}{c}\text { TSS/ } \\
\text { Acidity }\end{array}$ & $\begin{array}{c}\text { Ascorbic } \\
\text { acid } \\
\text { (mg/100gm) }\end{array}$ & $\begin{array}{c}\text { Total } \\
\text { Sugar } \\
(\%)\end{array}$ & $\begin{array}{l}\text { Reducing } \\
\text { Sugar }(\%)\end{array}$ \\
\hline $\mathbf{T}_{1}$ & \multirow[t]{6}{*}{$2,4-\mathrm{D}$} & \multirow[t]{3}{*}{10 PPM } & 15 October & 8.97 & 0.66 & 14.35 & 47.86 & 6.84 & 3.77 \\
\hline $\mathbf{T}_{2}$ & & & 15 November & 8.88 & 0.69 & 13.82 & 45.63 & 6.57 & 3.09 \\
\hline $\mathbf{T}_{3}$ & & & $\begin{array}{l}15 \text { October }+ \\
15 \text { November }\end{array}$ & 9.47 & 0.65 & 14.52 & 48.06 & 7.00 & 3.81 \\
\hline $\mathbf{T}_{4}$ & & \multirow[t]{3}{*}{20 PPM } & 15 October & 9.17 & 0.69 & 12.84 & 46.68 & 6.71 & 3.56 \\
\hline $\mathbf{T}_{5}$ & & & 15 November & 9.32 & 0.76 & 12.28 & 45.63 & 6.58 & 3.44 \\
\hline $\mathbf{T}_{6}$ & & & $\begin{array}{l}15 \text { October }+ \\
15 \text { November }\end{array}$ & 10.20 & 0.61 & 15.30 & 49.83 & 7.48 & 4.07 \\
\hline $\mathbf{T}_{7}$ & \multirow[t]{6}{*}{ GA3 } & \multirow[t]{3}{*}{25 PPM } & 15 October & 8.43 & 0.71 & 12.32 & 44.19 & 6.25 & 2.97 \\
\hline $\mathbf{T}_{8}$ & & & 15 November & 8.50 & 0.72 & 12.49 & 43.67 & 6.12 & 2.87 \\
\hline $\mathbf{T}_{9}$ & & & $\begin{array}{l}15 \text { October }+ \\
15 \text { November }\end{array}$ & 8.70 & 0.73 & 12.28 & 44.55 & 6.22 & 2.96 \\
\hline$T_{10}$ & & \multirow[t]{3}{*}{50 PPM } & 15 October & 8.75 & 0.72 & 12.10 & 45.11 & 6.20 & 2.92 \\
\hline $\mathbf{T}_{11}$ & & & 15 November & 8.13 & 0.71 & 12.50 & 43.96 & 6.48 & 2.94 \\
\hline$T_{12}$ & & & $\begin{array}{l}15 \text { October }+ \\
15 \text { November }\end{array}$ & 9.28 & 0.70 & 13.32 & 44.31 & 6.28 & 2.94 \\
\hline $\mathbf{T}_{13}$ & \multirow[t]{6}{*}{ NAA } & \multirow[t]{3}{*}{10 PPM } & 15 October & 9.18 & 0.72 & 12.76 & 43.57 & 6.42 & 2.95 \\
\hline $\mathbf{T}_{14}$ & & & 15 November & 9.35 & 0.68 & 13.68 & 46.04 & 6.70 & 3.51 \\
\hline $\mathbf{T}_{15}$ & & & $\begin{array}{l}15 \text { October }+ \\
15 \text { November }\end{array}$ & 9.85 & 0.67 & 14.00 & 46.55 & 6.80 & 3.68 \\
\hline $\mathbf{T}_{16}$ & & \multirow[t]{3}{*}{20 PPM } & 15 October & 9.50 & 0.68 & 13.79 & 46.01 & 6.65 & 3.38 \\
\hline $\mathbf{T}_{17}$ & & & 15 November & 9.62 & 0.64 & 14.85 & 48.28 & 7.30 & 4.04 \\
\hline $\mathbf{T}_{18}$ & & & $\begin{array}{l}15 \text { October }+ \\
15 \text { November }\end{array}$ & 10.52 & 0.58 & 15.85 & 50.90 & 7.76 & 4.25 \\
\hline$T_{19}$ & $\begin{array}{c}\text { CONTRO } \\
\text { L }\end{array}$ & & & 8.12 & 0.73 & 11.17 & 42.14 & 5.44 & 2.85 \\
\hline CD & & & & 0.13 & 0.05 & 0.68 & 1.19 & 0.38 & 0.027 \\
\hline $\operatorname{SEM}( \pm)$ & & & & 0.047 & 0.018 & 0.238 & 0.416 & 0.135 & 0.09 \\
\hline
\end{tabular}


Table.2 Effect of different treatment on phenolic content, total flavonoids, carotenoid content, antioxidant activity

\begin{tabular}{|c|c|c|c|c|c|c|c|}
\hline Treatment & Chemical & Concentration & Date of spray & $\begin{array}{c}\text { Phenolic } \\
\text { content } \\
\text { (mg/100g } \\
\text { FW) }\end{array}$ & $\begin{array}{c}\text { Total } \\
\text { Flavanoids } \\
\text { content } \\
\text { (mg/100g } \\
\text { FW) }\end{array}$ & $\begin{array}{l}\text { Carotenoid } \\
\text { content } \\
(\mathrm{mg} / \\
100 \mathrm{~g} \mathrm{fw})\end{array}$ & $\begin{array}{c}\text { Antioxidant } \\
\text { capacity }(\mu \mathrm{mo} \\
\text { trolox } / 100 \mathrm{~g} \\
\text { fw })\end{array}$ \\
\hline $\mathbf{T}_{1}$ & \multirow[t]{6}{*}{$2,4-\mathrm{D}$} & \multirow[t]{3}{*}{10 PPM } & 15 October & 0.732 & 3.51 & 0.254 & 0.179 \\
\hline $\mathbf{T}_{2}$ & & & 15 November & 0.739 & 3.61 & 0.356 & 0.178 \\
\hline $\mathbf{T}_{3}$ & & & $\begin{array}{l}15 \text { October }+ \\
15 \text { November }\end{array}$ & 0.742 & 3.70 & 0.385 & 0.192 \\
\hline $\mathbf{T}_{4}$ & & \multirow[t]{3}{*}{20 PPM } & 15 October & 0.745 & 3.66 & 0.343 & 0.162 \\
\hline $\mathbf{T}_{5}$ & & & 15 November & 0.765 & 3.69 & 0.358 & 0.186 \\
\hline $\mathbf{T}_{6}$ & & & $\begin{array}{l}15 \text { October }+ \\
15 \text { November }\end{array}$ & 0.747 & 3.78 & 0.282 & 0.178 \\
\hline $\mathbf{T}_{7}$ & \multirow[t]{6}{*}{ GA3 } & \multirow[t]{3}{*}{25 PPM } & 15 October & 0.753 & 3.56 & 0.267 & 0.148 \\
\hline $\mathbf{T}_{8}$ & & & 15 November & 0.745 & 3.59 & 0.207 & 0.115 \\
\hline $\mathbf{T}_{9}$ & & & $\begin{array}{l}15 \text { October }+ \\
15 \text { November }\end{array}$ & 0.756 & 3.45 & 0.265 & 0.156 \\
\hline $\mathbf{T}_{10}$ & & \multirow[t]{3}{*}{50 PPM } & 15 October & 0.768 & 3.41 & 0.222 & 0.199 \\
\hline $\mathbf{T}_{11}$ & & & 15 November & 0.784 & 3.61 & 0.291 & 0.103 \\
\hline $\mathbf{T}_{12}$ & & & $\begin{array}{l}15 \text { October }+ \\
15 \text { November }\end{array}$ & 0.746 & 3.71 & 0.291 & 0.149 \\
\hline $\mathbf{T}_{13}$ & \multirow[t]{6}{*}{ NAA } & \multirow[t]{3}{*}{10 PPM } & 15 October & 0.759 & 3.68 & 0.375 & 0.123 \\
\hline $\mathbf{T}_{14}$ & & & 15 November & 0.735 & 3.72 & 0.349 & 0.167 \\
\hline $\mathbf{T}_{15}$ & & & $\begin{array}{l}15 \text { October }+ \\
15 \text { November }\end{array}$ & 0.748 & 3.63 & 0.289 & 0.174 \\
\hline $\mathbf{T}_{16}$ & & \multirow[t]{3}{*}{20 PPM } & 15 October & 0.756 & 3.68 & 0.288 & 0.177 \\
\hline $\mathbf{T}_{17}$ & & & 15 November & 0.730 & 3.69 & 0.261 & 0.125 \\
\hline $\mathbf{T}_{18}$ & & & $\begin{array}{l}15 \text { October }+ \\
15 \text { November }\end{array}$ & 0.766 & 3.72 & 0.385 & 0.193 \\
\hline$T_{19}$ & Control & & & 0.753 & 3.43 & 0.322 & 0.176 \\
\hline CD & & & & NS & $\mathrm{NS}$ & 0.08 & 0.03 \\
\hline $\operatorname{SEM}( \pm)$ & & & & NS & & 0.028 & 0.0024 \\
\hline
\end{tabular}

Results also indicates that spray of different PGR's does not have much influence on carotenoid content, antioxidant capacity, total sugar and reducing sugar. The results are similar to the findings of Saleem et al. (2007) and Nawaz et al.(2008).

In conclusion, the present findings clearly indicate that foliar application of NAA 20 ppm on $15^{\text {th }}$ October $+15^{\text {th }}$ November improved TSS, TSS/Acidity ratio, Ascorbic Acid, Total Sugar and reducing sugar and minimised acidity in kinnow mandarin. All the PGR's does not showed much influence on carotenoid content, antioxidant capacity and total sugar. Thus, NAA could be exogenously applied to enhance fruit biochemical parameters to maximize the economic value of kinnow. 


\section{References}

Anonymous (2014). National Horticulture Board, Gurgaon, Haryana.

Ashraf, M.Y., Yaqub, M., Akhtar, J., Khan, M.A. and Ebert, G., 2012. Control of excessive fruit drop and improvement in yield and juice quality of Kinnow through nutrient management. Pak. J. Bot., 44: 259-265.

Ahmed, W., Ziaf, K., Nawaz, M.A. and Saleem, B.A., 2007. Studies on combining ability of citrus hybrids with commercial indigenous cultivars. Pak. J. Bot., 39(1): (47-55).

Almeida, I., Leite, I.M., Rodrigues, J.D. and Ono, E.O., 2004. Application of plant growth regulators at pre-harvest for fruit development of 'PERA' oranges. Braz. Arch. Bio. Technol., 47(7): 658-662.

Agusti , M., Almela, V., Aznar, Juan, M. and Veres, V.,1995.Recent findings on the mechanism of action of the synthesis auxins used to improve fruit size of citrus. Proc . Int. Soc. Citriculture, 2:922-928.

Ahmed , W., Pervez, M.A., Amjad, M., Khalid, M., Ayyub, C.M. and Nawaz, M.A., 2006. Effect of stonic combination on the growth and ysield of Kinnow mandarin. Pak. J. Bot., 38(3): 603-612

Bose, T.K., Hussain, T., Mitra, S.K. and Roy A. 1988. Control of pre mature fruit drop in mandarin orange. Haryana $J$. Hort. Sci. 17(3-4): 140-143. Bhati ,A.S., Kanwar, J., Naruka, I.S., Tiwari, R., Gallani, R., and Singh, O. 2016.An international journal of life science.
11(4): 2665-2668.

Bhatt , B.B., Singh, K.K. and Rawat, S.S., 2017. Influence of Foliar Application of Bio-Regulators and Nutrients on the Fruit Quality of Lemon (Citrus limon Burma.) Cv. Pant Lemon-1.Int.J.Curr. Microbial.App.sci. 6(4):2451-2458.

Bons, H.K., Kaur, N,. and Rattanpal, H.S., 2015. Quality and quantity improvement of citrus: role of plant growth regulators. International journal of Agriculture, Environment and Biotechnology., 8(2): 433-447.

Ghosh, S.N., Bera, B., and Roy, S., 2012. Influnence of plant growth regulators on fruit production of sweet orange. Journal of crop and weed,. 8(2): 83-85.

Jahromi, N.S.M., Kholdebarin, B., and Rajaei, H., 2013. Fruit drop prevention in local tangerine by growth regulators in response to application time. Indian $J$. Hort., 70(7), December 2013: 491-495.

Mir, H., and Itoo, H., 2017. Effect of foliar spray of 2,4-D and frequency of application on preharvest fruit drop, yield and quality in Kinnow mandarin. Indian journal of ecology.,44(3): 534538.

Nirgude , V., Kumari, K., Mankar, A., Kumar, v., and Spandana, M., 2016. Response of fertigation on phenolphysiological status of Citrus sinensis Osbeck cv. Mosambi under high density planting. Journal of applied and natural science., 8 (3):under high density planting. Journal of applied and natural science., 8 (3): 1306-1311.

\section{How to cite this article:}

Aditi Bharti, Kumari Karuna, Hidayatullah Mir, Shashi Kala and Ankita Aman. 2020. Effect of Time of Application, Types and Concentrations of Plant Growth Regulators on Biochemical Parameters of Kinnow Mandarin. Int.J.Curr.Microbiol.App.Sci. 9(03): 824-830. doi: https://doi.org/10.20546/ijcmas.2020.903.096 